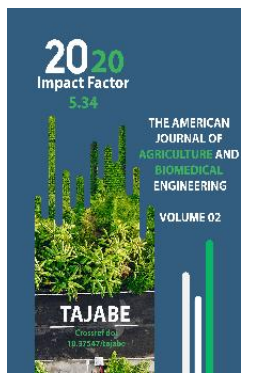

Journal Website: http://usajournalshub.c om/index,php/tajabe

Copyright: Original content from this work may be used under the terms of the creative commons attributes 4.0 licence.

\section{Bentonite Silt, Effects Of Mineral Fertilizer Norms And Irrigation Regulations On Autumn Wheat Yield}

\author{
Abdurakhmonov Sodikjon Obidovich \\ Doctor Of Agricultural Sciences, Andijan Branch Of Tashkent State Agrarian University, \\ Andijan, Uzbekistan.
}

Abdullaev Ismoiljon Ibrahimjonovich

Phd, Andijan Branch Of Tashkent State Agrarian University, Andijan, Uzbekistan.

\title{
ABSTRACT
}

In the conditions of typical gray soils of Tashkent region, before sowing of winter wheat under the plow once in three years in addition to the norms of mineral fertilizers N200P140K100 ва $\mathrm{N} 150 \mathrm{P} 105 \mathrm{~K} 75 \mathrm{~kg} /$ ha 1.5-3.0-4.5 t per hectare. The effect of irrigation on soil agrophysical properties and plant growth and grain yield was studied for three years in the order of 60-70-60 and 70-80$70 \%$ of the soil moisture before irrigation during the period of application, using bentonite mud.

The obtained data show that the pre-irrigation soil moisture is irrigated in the order of $60-70-60 \%$ relative to LMFC, in addition to the norms of mineral fertilizers (N200P140K100 ва N150P105K75 / hec) 1.5-3.0-4.5 t per hectare. germination of seedlings 18-16 compared to control options when using bentonite silts in the amount of $18-16 ; 33-28$ and $46-44 \mathrm{m2} /$ piece, total number of stems 49.0-81.6; 96.6-99.4; 104.7-108.3 m2 / piece, and the number of productive stems is 47.4-76.1; 97.7100.3; 102.2-107.6 m2 / grain was observed, grain yield was 6.9-11.3; 8.8-13.4; It was noted that it was higher than 10.1-14.7 ts / hec.

Pre-irrigation soil moisture is irrigated at $70-80-70 \%$ relative to the LFMC, in addition to the norms of mineral fertilizers N200P140K100 ва N150P105K75 kg / hec, 1.5-3.0-4.5 t per hectare. The number of seedlings germinated per $1 \mathrm{~m} 2$ in the variants using bentonite mud in the amount of 22-41-50 to 1536-51 m2 / piece compared to the control variant, the total number of stems 44.2-42.4; 55.8-60.8; 86.5-92.3 m2 / piece, number of productive stems 47.5-61.2; 60.2-79.6; Found to be higher than 90.0$108.6 \mathrm{mz}$ / unit, 5.6-9.4 per hectare; 8.2-11.9; 10.0-13.6 quintals of additional grain yield was obtained.

\section{KEYWORDS}

Typical gray soil, soil volume weight, soil water permeability, mineral fertilizers, bentonite sludge, winter wheat, seedling thickness, total and productive stem, LFMC, grain and straw harvest. 


\section{INTRODUCTION}

Today, 45 million people a year live in 45 countries around the world. tons of nontraditional agro-ores are mined and widely used in various sectors of the economy, including agriculture. In 92 countries of the world $231 \mathrm{mln}$. Wheat seeds have been sown on more than a hectare of land, resulting in 760.4 million tons of grain. Wheat grain is one of the most widely consumed food products of the world's population and is the leading crop in terms of area among cereal crops. A report by the United Nations (UN) and the Food and Agriculture Organization (FAO) in October 2019 showed that wheat production in the world is increasing year by year. According to the data, the gross grain yield of wheat in 2016 was 729 million tons, in 2017 749 million tons, in 2018 - 760.4 million tons, and in 2018 the gross grain yield of total grain crops was 2658.1 million tons. tons, of which $28.6 \%$ was wheat grain, and in 2019 it was 2720.0 million tons, of which $28.9 \%$ was wheat grain, and grain production increased by 65.3 million tons or $2.5 \%$ compared to 2018 .

In the world's leading wheat-growing countries, guidelines have been developed and scientifically based for the use of nontraditional agro-ores in a variety of soil conditions as a supplement to mineral fertilizers. The use of non-traditional agro-ores in the soil as a resource-saving technology has improved the agrophysical and agrochemical properties of the soil, accelerated biological processes in the soil, increased the rate of assimilation of applied mineral fertilizers by plants and, consequently, improved grain quality. It should be noted that the development of agro-measures to save water and mineral fertilizers, using non-traditional agro-ores in the production of high-quality grain from winter wheat is a topical issue.

Foreign scientists M. El-Nennah, A. Abdel Latif, Soils Dept, Ain Shams, Dr. Zoltán Adamis, József Fodor, János Kátai, Magd, Magd Lazányi, Edina Veres Lukácsné, Zsolt Sándor, A.V.Tsygankov, E.V.Agafonov, A.V.Tsygankov, V.V.Turchin, A.A.Gromakov, A.S.Sokolov, U.G.Distanov , Ya.Steyskal, K.Vnouchek, scientists of the Republic S.N.Ryjov, M.G.Tlyavov, L.N.Slesareva, A.Djalalova, D.Alimardanov, R.Nazarov, E.M.Belousov, D.A. Many scientific researches have been carried out by Tungushova, S.O. Abdurahmanov, S.M. Boltaev and others.

Bentonite slit is a natural element rich in minerals, and many species of it are found in nature. Bentonite sludge not only fills the soil with a shortage of microelements, but also serves to improve its reclamation condition (M. El-Nennah, A. Abdel Latif, Soils Dept, Ain Shams (1979).

Studies by Russian scientists AS Sokolov (1982) and UG Distanov (1985) have shown that the specificity of bentonite, its physical and chemical properties, the source of micronutrients in terms of composition, which helps the absorption of mineral fertilizers, water and soil while increasing the ion absorption properties, it has a comprehensive effect on increasing soil fertility.

They concluded that reducing the amount of harmful salts in the soil helps to increase physiological processes, as well as increases the plant's resistance to various diseases.

According to AV Tsygankov (2011), in the conditions of black chestnut soils of Russia, 
the application of bentonite mud to winter wheat in the amount of $7.5 \mathrm{t} / \mathrm{ha}$, up to $15.1 \%$ compared to the control variant of grain yield, 52 , Increased to $2 \%$. In addition to these norms of bentonite sludge, when mineral fertilizers were applied at the rates of N60P60 and $\mathrm{N} 60 \mathrm{P} 60 \mathrm{~K} 60 \mathrm{~kg} / \mathrm{ha}$, the grain yield was 25.4$26.7 \%$ higher than the control variant.

According to EV Agafonov, AV Tsygankov, VV Turchin, AA Gromakov (2013), when using bentonite mud in the amount of $7.5 \mathrm{t} / \mathrm{ha}$ under driving in the conditions of black chestnut soils of Russia, had a positive effect on the increase of mobile forms of nitrate, phosphorus and potassium in the soil, resulting in an increase in winter wheat yield to $15.1 \%$.

According to DA Tungushova, EM Belousov, SO Abdurahmanov, SM Boltaev (2007), the composition of agro-ores, which are a source of food for plants, consists of macro-micro elements: phosphorus 1-8\%, potassium 0 , 7$3.6 \%$ carbon $0.7-4.9 \%$, as well as copper, boron, zinc, manganese, molybdenum, cobalt and others. Deposition of bentonite sludge and glauconite sand into the soil prevents leaching of nutrients along with soil volume weight, moisture capacity, water retention ability, and improved soil structure. In the conditions of typical gray soils of Tashkent region, the use of hammer bentonite mud under driving at the rate of $750-3000 \mathrm{~kg}$ cotton yield 3.4-3.2 ts / hec, the use of glauconite sand at the rate of 750-1500 kg per hectare 4.5-3.1 allowed to increase ts / hec.

According to S.Abdurahmanov (2008), in the conditions of grazing soils of Surkhandarya region, before sowing of cotton, bentonite mud in the amount of $9000 \mathrm{~kg} / \mathrm{ha}$ was applied under the autumn plowing, and during the growing season the pre-irrigation soil moisture was $70-70-60 \%$ of LFMC with the application of mineral fertilizers NPK: 200140-100 and 150-105-75 kg / ha, with an additional yield of 4.2-6.3 quintals of cotton per hectare, $820 \mathrm{~m} 3$ of water was saved during the season.

From the analysis of the literature we can see that the application of bentonite sludge to the soil has a positive effect on the agrophysical and aquatic physical properties of the soil, resulting in improved plant growth and nutrient uptake, which has been proven by many scientists.

However, no research has been conducted to study the combined effects of bentonite sludge, mineral fertilizer standards and irrigation regimes on the growth, development and grain yield of winter wheat in the conditions of typical gray soils of Tashkent region.

\section{PROCEDURE AND METHOD OF CONDUCTING} THE EXPERIMENT

This research was conducted in 2008-2011 at the Experimental Site of the Research Institute of Cotton Breeding, Seed Production and Agrotechnology (PSUEAITI). This area is located in Kibray district of Tashkent region, 7$8 \mathrm{~km}$ from the Chirchik river. in the distance, to the right of the Gray Water Canal.

The soil of the PSUEAITI experimental plot is a typical gray soil with ancient irrigation, groundwater depth 18-20 m, medium and heavy sandy, high carbonate, humus content $1.0-1.5 \%$, total nitrogen $0.08-0,1$ percent, phosphorus $0.2-0.3$ percent. Due to the high content of saturated cations, biological processes are accelerated.

Prior to the experiment (2008), 0-30 and 30$50 \mathrm{~cm}$ of soil were measured in five-point envelopes to determine the nutrient content of the field soil. Initial soil samples were taken 
from the layers and analyzed. According to the data obtained, the soil is $0-30 \mathrm{~cm}$. The average humus content in the stratum was $0.897 \%$, total nitrogen was $0.090 \%$, and total phosphorus was $0.096 \%$. The humus content in the stratum was $0.782 \%$, total nitrogen $0.068 \%$ and total phosphorus $0.063 \%$.

Table 1

Early agrochemical properties of experimental field soils (2008)

\begin{tabular}{|c|c|c|c|c|c|c|c|}
\hline \multirow{2}{*}{$\begin{array}{c}\text { Points } \\
\text { No }\end{array}$} & Layer of & \multicolumn{2}{|c|}{ General figures, $\%$} & \multicolumn{2}{c|}{ Active figures, $\mathrm{Mr} / \mathrm{Kr}$. } \\
\cline { 3 - 8 } & cM. & haze & N & $\mathbf{P}$ & $\mathbf{N}-\mathrm{NO}_{3}$ & $\mathbf{P}_{2} \mathrm{O}_{5}$ & $\mathbf{K}_{\mathbf{2}} \mathbf{O}$ \\
\hline \multirow{2}{*}{ Medium } & $0-30$ & 0,897 & 0,090 & 0,096 & 3,273 & 21,62 & 170 \\
\cline { 2 - 8 } & $30-50$ & 0,782 & 0,068 & 0,063 & 2,924 & 18,32 & 132 \\
\hline
\end{tabular}

In the experiment, two different fertilizer

The amount of mobile nutrients in the soil is 030 and $30-50 \mathrm{~cm}$. The average nitrate nitrogen in the strata was 3,273-2,924 mg / kg, mobile phosphorus was 21.62-18.32 mg / kg, and exchangeable potassium was $170-132 \mathrm{mg} / \mathrm{kg}$, and the analysis of the obtained data showed that the field was poorly supplied with nutrients. .

The experimental system consisted of 16 variants, placed in 3 iterations, one tier. In the experimental field, the width of the edges is $60 \mathrm{~cm}$, the length of the edges is $100 \mathrm{~m}$. In the experiment, Moskvich variety of winter wheat was planted. The area of each plot is $480 \mathrm{~m} 2$, of which the area to be taken into account is $240 \mathrm{~m} 2$. The total area of the experiments is 2.5 hectares. rates ((N200P140K100 and N150P105K75 кг/га $\mathrm{kg} / \mathrm{ha})$, two different irrigation regimes for LFMC $70-80-70$ and $60-70-60 \%$, and three different types of bentonite sludge from the Bolgali deposit 1.5-3.0-4, 5 t / ha standards are set.

\section{THE PURPOSE OF THE STUDY}

To determine the amount of mineral fertilizers and water requirements of winter wheat in the application of bentonite mud under the driving conditions of typical gray soils of Tashkent region and to assess the impact of non-traditional crops on wheat growth, development and grain yield. 
Table 2

Experimental system (2008-2011)

\begin{tabular}{|c|c|c|c|c|c|c|}
\hline \multirow[t]{2}{*}{ № } & \multirow{2}{*}{ Variants } & \multicolumn{3}{|c|}{$\begin{array}{l}\text { Fertilizer annual } \\
\text { amount, kg/ha }\end{array}$} & \multirow{2}{*}{\multicolumn{2}{|c|}{$\begin{array}{c}\text { Moisture of soil } \\
\text { according to LFMC, \%. }\end{array}$}} \\
\hline & & $\mathbf{N}$ & $\mathrm{P}_{2} \mathrm{O}_{5}$ & $\mathrm{~K}_{2} \mathrm{O}$ & & \\
\hline 1 & Without bentonite & 200 & 140 & 100 & \multirow{8}{*}{$\begin{array}{l}8 \\
1 \\
1 \\
1 \\
0 \\
0\end{array}$} & \multirow{8}{*}{$\begin{array}{l}0 \\
1 \\
0 \\
\infty \\
1 \\
0\end{array}$} \\
\hline 2 & Without bentonite & 150 & 105 & 75 & & \\
\hline 3 & $1500 \mathrm{~kg} / \mathrm{ha}$ bentonite & 200 & 140 & 100 & & \\
\hline 4 & $1500 \mathrm{~kg} / \mathrm{ha}$ bentonite & 150 & 105 & 75 & & \\
\hline 5 & $3000 \mathrm{~kg} / \mathrm{ha}$ bentonite & 200 & 140 & 100 & & \\
\hline 6 & $3000 \mathrm{~kg} / \mathrm{ha}$ bentonite & 150 & 105 & 75 & & \\
\hline 7 & $4500 \mathrm{~kg} / \mathrm{ha}$ bentonite & 200 & 140 & 100 & & \\
\hline 8 & $4500 \mathrm{~kg} / \mathrm{ha}$ bentonite & 150 & 105 & 75 & & \\
\hline
\end{tabular}

Note: The norms of bentonite mud shown in the experimental system were applied once before driving in the 1st year before planting, and the effect was studied for 3 years.

\section{RESEARCH METHOD}

Placement, calculations and observations of field experiments were carried out on the basis of methodical manuals "Methods of agrochemical, agrophysical and microbiological research in polyfiber districts", "Methods of conducting field experiments" (UzPITI). Statistical analysis of the obtained results was performed on the basis of Microsoft Excel program and B.A. Dospekhov's methodical manual and economic efficiency N.A. Baranov's method.

\section{FINDINGS FROM THE STUDY}

The soil volume weight of the experimental field was measured at the beginning and end of the vegetation, using cylinders with a volume of $500 \mathrm{~g} / \mathrm{cm} 3$, every $10 \mathrm{~cm}$ of soil. 50 $\mathrm{cm}$ from the layer. depth samples were taken and determined. 
At the beginning of the experiment (2008), samples were taken and analyzed from five points of the field in the envelope method from the plowed $(0-30 \mathrm{~cm})$ and plowed $(30-$ $50 \mathrm{~cm}$ ) layers of soil, and an average of $0-30$ $\mathrm{cm}$ from five points. in the layer, the bulk density of the soil is $1.35 \mathrm{~g} / \mathrm{cm} 3,30-50 \mathrm{~cm}$. layer was $1.40 \mathrm{~g} / \mathrm{cm} 3$.

By the end of the experiment (2011), when analyzing the volume weight of the soil in the variant section, the pre-irrigation soil moisture was irrigated at $60-70-60 \%$ relative to LFMC, and 1.5-3.0- / ha in addition to mineral fertilizers N200P140K100kg / ha. 4.5 t. When applying bentonite mud in the amount of 0-30 $\mathrm{cm}$ of soil relative to the control options. in a layer of $0.04-0.05-0.05 \mathrm{~g} / \mathrm{cm} 3,30-50 \mathrm{~cm}$. In addition to the norms of mineral fertilizers N150P105K75kg / ha, 1.5-3.0-4.5 t per hectare was observed. When using bentonite mud in the amount of $0-30 \mathrm{~cm}$, the volume weight of the soil relative to the control options is $0-30$ $\mathrm{cm}$. in the layer 0.02-0.03-0.05 $\mathrm{g} / \mathrm{cm} 3,30-50$ $\mathrm{cm}$. and 0.09-0.11-0.11 g/cm3.

In the second irrigation mode (70-80-70\% of the LFMC), in addition to the norm of mineral fertilizers N200P140K100 kg / ha, bentonite mud in the amount of 1.5-3.0-4.5 $\mathrm{t} /$ ha was applied under the plow, in accordance with the above laws. the bulk density of the soil relative to the control option at the end, 0-30 $\mathrm{cm}$. layer 0.04-0.06-0.08 g/ cm3 per hectare, 30-50 cm. 0.05-0.06-0.08 $\mathrm{g} / \mathrm{cm} 3$ in the stratum, in addition to the norm of mineral fertilizers N150P105K75 kg / ha, when applying bentonite mud in the amount of 1.5-3.0-4.5 $\mathrm{t} /$ ha. $30 \mathrm{~cm}$. in the layer $0.04-0.07-0.08 \mathrm{~g} / \mathrm{cm} 3$, $30-50 \mathrm{~cm}$. was found to be less dense by $0.03-0.04-0.07 \mathrm{~g} / \mathrm{cm} 3$.

\section{Table 3}

Soil volume weight of the experimental field, $\mathrm{g} / \mathrm{sm}^{3}$

\begin{tabular}{|c|c|c|c|c|}
\hline \multirow{2}{*}{ № } & \multirow{2}{*}{ Variants } & \multirow{2}{*}{$\begin{array}{l}\text { according to } \\
\text { LFMC, \%. }\end{array}$} & \multicolumn{2}{|c|}{ 2008- year } \\
\hline & & & 0-30 & $30-50$ \\
\hline & \multicolumn{2}{|c|}{ At the beginning of growing } & 1,35 & 1,40 \\
\hline & \multicolumn{2}{|c|}{ At the end of growing } & \multicolumn{2}{|c|}{ 2011- year } \\
\hline 1 & Without bentonite & \multirow{3}{*}{$60-70-60$} & 1,40 & 1,46 \\
\hline 2 & Without bentonite & & 1,38 & 1,47 \\
\hline 3 & $1500 \mathrm{~kg} / \mathrm{ha}$ bentonite & & 1,36 & 1,41 \\
\hline
\end{tabular}


The American Journal of Agriculture And Boimedical Engineering (ISSN - 2689-1018)

Published: August 30, 2020 | Pages: 73-97

Doi: https://doi.org/10.37547/tajabe/Volume02Issue08-09

\begin{tabular}{|c|c|c|c|c|}
\hline 4 & $1500 \mathrm{~kg} / \mathrm{ha}$ bentonite & & 1,36 & 1,38 \\
\hline 5 & $3000 \mathrm{~kg} / \mathrm{ha}$ bentonite & & 1,35 & 1,38 \\
\hline 6 & $3000 \mathrm{~kg} / \mathrm{ha}$ bentonite & & 1,35 & 1,36 \\
\hline 7 & $4500 \mathrm{~kg} / \mathrm{ha}$ bentonite & & 1,35 & 1,36 \\
\hline 8 & $4500 \mathrm{~kg} / \mathrm{ha}$ bentonite & & 1,33 & 1,36 \\
\hline 9 & Without bentonite & \multirow{8}{*}{$70-80-70$} & 1,44 & 1,51 \\
\hline 10 & Without bentonite & & 1,44 & 1,49 \\
\hline 11 & $1500 \mathrm{~kg} / \mathrm{ha}$ bentonite & & 1,40 & 1,46 \\
\hline 12 & $1500 \mathrm{~kg} / \mathrm{ha}$ bentonite & & 1,40 & 1,46 \\
\hline 13 & $3000 \mathrm{~kg} / \mathrm{ha}$ bentonite & & 1,38 & 1,45 \\
\hline 14 & $3000 \mathrm{~kg} / \mathrm{ha}$ bentonite & & 1,37 & 1,45 \\
\hline 15 & $4500 \mathrm{~kg} / \mathrm{ha}$ bentonite & & 1,36 & 1,43 \\
\hline 16 & $4500 \mathrm{~kg} / \mathrm{ha}$ bentonite & & 1,36 & 1,42 \\
\hline
\end{tabular}

Accordingly, it was found that the

Another agrophysical property of soil is water permeability. The permeability of the soil itself is called the water permeability and its amount is measured by the amount of water that passes through the soil over a period of time ( $\mathrm{mm}$. hour or $\mathrm{m} 3 / \mathrm{ha})$.

Based on this, we analyzed the water permeability of the soil in an envelope method from five points of the field area at the beginning of the 2008 experiment. experimental field soaked an average of 870 m3 / ha of water for 6 hours.

Towards the end of the experiment (2011), when the water permeability of the soil was determined in the cross section of the options, it was found that the irrigation norms in the experiment also had an effect on the permeability in accordance with the law. However, in the variants where bentonite mud was used, it was observed that the soil 
The American Journal of Agriculture And Boimedical Engineering (ISSN - 2689-1018)

Published: August 30, 2020 | Pages: 73-97

Doi: https://doi.org/10.37547/tajabe/Volumeo2Issueo8-09

water permeability was higher in both irrigation regimes than in the control.

Table 4

Soil water permeability in the experimental field, $\mathrm{m}^{3} / \mathrm{ha} /$ hour

\begin{tabular}{|c|c|c|c|}
\hline № & Variants & $\begin{array}{l}\text { Order of watering, } \\
\text { according to LFMC. }\end{array}$ & $\begin{array}{c}\text { At the end of } \\
\text { experiment, during } 6 \\
\text { hours }\end{array}$ \\
\hline & At the beginning of $c$ & eriment (2008 year) & 870 \\
\hline & \multicolumn{2}{|c|}{ At the end of growing } & 2011-year \\
\hline 1 & Without bentonite & \multirow{8}{*}{$60-70-60 \%$} & 855 \\
\hline 2 & Without bentonite & & 860 \\
\hline 3 & $1500 \mathrm{~kg} / \mathrm{ha}$ bentonite & & 865 \\
\hline 4 & $1500 \mathrm{~kg} / \mathrm{ha}$ bentonite & & 865 \\
\hline 5 & $3000 \mathrm{~kg} / \mathrm{ha}$ bentonite & & 875 \\
\hline 6 & $3000 \mathrm{~kg} / \mathrm{ha}$ bentonite & & 890 \\
\hline 7 & $4500 \mathrm{~kg} / \mathrm{ha}$ bentonite & & 877 \\
\hline 8 & $4500 \mathrm{~kg} / \mathrm{ha}$ bentonite & & 890 \\
\hline 9 & Without bentonite & $70-80-70 \%$ & 760 \\
\hline
\end{tabular}




\begin{tabular}{|c|c|c|}
\hline 10 & Without bentonite & 765 \\
\hline 11 & $1500 \mathrm{~kg} / \mathrm{ha}$ bentonite & 865 \\
\hline 12 & $1500 \mathrm{~kg} / \mathrm{ha}$ bentonite & 860 \\
\hline 13 & $3000 \mathrm{~kg} / \mathrm{ha}$ bentonite & 867 \\
\hline 14 & $3000 \mathrm{~kg} / \mathrm{ha}$ bentonite & 865 \\
\hline 15 & $4500 \mathrm{~kg} / \mathrm{ha}$ bentonite & 863 \\
\hline 16 & $4500 \mathrm{~kg} / \mathrm{ha}$ bentonite & 862 \\
\hline
\end{tabular}

The obtained data show that in addition to the norms of mineral fertilizers N200P140K100 and $\mathrm{N} 150 \mathrm{P} 105 \mathrm{~K} 75 \mathrm{~kg} / \mathrm{ha}, 1.5-3.0-4.5 \mathrm{t}$ per hectare. bentonite turbidity in the amount of $60-70-60 \%$ of the pre-irrigation soil moisture relative to the LFMC in the irrigated variant, the water permeability of the soil in relation to the control variant $10-5 ; 20-30 ; 22-30 \mathrm{~m} 3 /$ ha, pre-irrigation soil moisture $70-70-70 \%$ relative to LFMC, and 105-95 in irrigated versions; 107$100 ; 103-97 \mathrm{~m} 3$ / ha was found to absorb a lot of water.

However, it can be concluded from the data obtained that an increase in the number of irrigations leads to an increase in volume weight in the soil and a deterioration in water permeability, in which case the application of bentonite mud had a positive effect on soil volume weight and water permeability.

At the time of irrigation of the experimental options, the threshold was 50 and $25 \mathrm{~cm}$. the amount of water used for irrigation was determined using a Chippoletti water meter with a width.
Analyzing the experimental data, the norms of mineral fertilizers N150P105K75kg / ha were applied, and when the pre-irrigation soil moisture was $60-70-60 \%$ relative to the LFMC, the control option was irrigated a total of 3 times during the application period, $0-2-1$ in the irrigation system. 1 time (irrigation rate $860 \mathrm{m3} / \mathrm{ha}$ ), 1 time during sowing (irrigation rate $880 \mathrm{~m} 3 / \mathrm{ha}$ ), and 1 time during ripening period (irrigation rate $850 \mathrm{~m} 3$ / ha), seasonal irrigation rate was $3350 \mathrm{~m} 3$ In the case of bentonite mud in the amount of $1500 \mathrm{~kg} / \mathrm{ha}$ in addition to the norms of mineral fertilizers, a total of $2580 \mathrm{~m} 3 /$ ha of water was used during the growing season, irrigated 2 times during the growing season, $0-2-0$ irrigation system.

In addition to the norms of these mineral fertilizers, even when bentonite sludge is applied at high rates, ie in the amount of 3.0$4.5 \mathrm{t} / \mathrm{ha}$, it is necessary to irrigate a total of 2 times during the growing season in 0-1-1 irrigation system, seasonal water consumption is $2540 \mathrm{m3} / \mathrm{ha}$. and $2500 \mathrm{~m} 3$ / ha of water consumption. 
According to the data obtained, in addition to the norms of mineral fertilizers N150P105K75kg / ha, 1.5-3.0-4.5 t per hectare. It was found that in the variants using bentonite sludge in the amount of 770-810$850 \mathrm{~m} 3$ / ha compared to the control variant.

In the second irrigation procedure, the same patterns were repeated, with pre-irrigation soil moisture at $70-80-70 \%$ relative to LFMC, and 1.5-3.0-4.5 $\mathrm{t}$ per hectare in addition to the norm of mineral fertilizers N150P105K75kg I ha. The variants with bentonite mud were irrigated 3 times during the season in 1-1-1 and 0-2-1 systems, the seasonal irrigation norms were 3660-3500-3400 m3 / ha, and 630-790$890 \mathrm{~m} 3 /$ ha more than the control variant. was found to have been saved, and it was observed that the above laws had been proved.

The full germination of wheat sown in the fall depends on many factors, mainly the biological characteristics of the variety, planting times, soil moisture, fertilization with mineral fertilizers, temperature and others.

Data on seedling thickness of winter wheat during the growing season of 2009-2010 show that the effect of mineral fertilizers and bentonite mud norms on germination and seedling thickness of winter wheat was significant among the options.

In particular, pre-irrigation soil moisture is irrigated at $60-70-60 \%$ relative to the LFMC, in addition to the norms of mineral fertilizers (N200P140K100 and N150P105K75kg / ha) 1.53.0-4.5 t per hectare. when using bentonite muds in the amount of 18-16 compared to the control options; It was found that 33-28 and 46-44 m2 / piece of seedlings sprouted a lot.

In the second irrigation regime in the experiment (pre-irrigation soil moisture 70-
$80-70 \%$ relative to $\mathrm{LFMC}$ ), in addition to the two norms of mineral fertilizers (N200P140K100 ва N150P105K75kg / ha), 1.5-3 per hectare, in addition to the two norms of mineral fertilizers, while maintaining the above regularity. $0-4.5 \mathrm{t}$. The number of seedlings germinated per $1 \mathrm{~m} 2$ ranged from 290-309-318 to 276-297-312, while the number of seedlings per hectare increased from 22-41-50 to 15-36-51 m2 / unit compared to the control variant. observed.

With the autumn wheat, the period of time until the end of the application period is the viability of the plant. Survival varies depending on several factors: soil-climatic conditions, level of nutrition, planting times and standards, irrigation, biological characteristics of the variety. Data from experiments conducted during the growing season of 2009-2010 also to some extent confirmed the above ideas.

In particular, pre-irrigation soil moisture is irrigated at $60-70-60 \%$ relative to the LFMC, in addition to the norms of mineral fertilizers N200P140K100 kg / ha 1.5-3.0-4.5 t per hectare. It was observed that the death of seedlings in the winter with the use of bentonite mud in the amount of $0.6-1.0-1.4 \%$ less than the control option.

Irrigated in the same irrigation regime, in addition to the norms of mineral fertilizers N150P105K75 kg/ ha, 1.5-3.0-4.5 t per hectare. It was noted that the use of bentonite mud in the amount of $1.4-2.5-3.3 \%$ less than the control option.

The same pattern was observed in the second irrigation regime (70-80-70\% of the LFMC), in addition to the norms of mineral fertilizers N200P140K100 kg / ha, 1.5-3.0-4.5 t per hectare. In variants 11-13-15 with the use of bentonite mud in the amount of $0.3-1.4-1.9 \%$ 
compared to the control variant, in addition to the norms of mineral fertilizers $\mathrm{N} 150 \mathrm{P} 105 \mathrm{~K} 75$ $\mathrm{kg} /$ ha 1.5-3.0-4.5 per hectare t. In variants 12-14-16, where bentonite mud was applied in the amount of $1.7-3.3-3.9 \%$, it was observed that the loss of seedlings was low.

However, when the actual thickness of seedlings at the end of the application period was studied in terms of variants, it was observed that during the period from collection to the end of the ripening period, seedlings died under the influence of various factors.

According to the data obtained, pre-irrigation soil moisture is irrigated at $60-70-60 \%$ relative to LFMC, and in addition to the norm of mineral fertilizers N200P140K100 kg / ha, 1.5-
3.0-4.5 $t$ per hectare. By the end of the application period, the actual seedling thickness was 239-254-267 m2 / piece, the number of dead seedlings was $6.1-5.6-5.2 \%$, and the number of seedlings compared to the control variant was 3-5-7 variants. In addition to the norm of mineral fertilizers N150P105K 75 $\mathrm{kg} / \mathrm{ha}$, it was observed that the number of dead seedlings was higher by 19-34-47 $\mathrm{m2} /$ unit, the amount of dead seedlings was reduced by $0.6-1.1-1.5 \%, 1.5-3.0-4$ per hectare. $5 \mathrm{t}$. By the end of the validity period, the actual seedling thickness was 227-242-258 m2 / piece, the number of dead seedlings was 6.5$6.0-5.8 \%$, and the number of seedlings compared to the control was 18-33-49 $\mathrm{m} 2$ / unit, and the number of dead seedlings was found to be $0.7-1.2-1.4 \%$ lower.

Table 5

Effect of bentonite turbidity on experimental winter wheat germination and seedling thickness, 2010

\begin{tabular}{|c|c|c|c|c|c|}
\hline No & $\begin{array}{c}\text { The } \\
\text { number of } \\
\text { sprouted } \\
\text { seedlings } \\
\mathrm{m}^{2} / \text { piece }\end{array}$ & $\begin{array}{c}\text { The number } \\
\text { of seedlings } \\
\text { perished in } \\
\text { winter, \% }\end{array}$ & $\begin{array}{c}\text { The } \\
\text { number of } \\
\text { seedlings } \\
\text { obviated } \\
\text { winter, } \\
\mathrm{m}^{2} / \text { piece }\end{array}$ & $\begin{array}{c}\text { The number of } \\
\text { perished plants } \\
\text { from gathering } \\
\text { to the end of } \\
\text { maturing, \% }\end{array}$ & $\begin{array}{c}\text { Thumber } \\
\text { seedlings } \\
\text { at the end } \\
\text { of, } \\
\mathrm{m}^{2} / \mathrm{piece}\end{array}$ \\
\hline 1 & 259 & 8,9 & 236 & 6,7 & 220 \\
\hline 2 & 252 & 10,7 & 225 & 7,2 & 209 \\
\hline 3 & 277 & 8,3 & 254 & 6,1 & 239 \\
\hline
\end{tabular}


The American Journal of Agriculture And Boimedical Engineering (ISSN - 2689-1018)

Published: August 30, 2020 | Pages: 73-97

Doi: https://doi.org/10.37547/tajabe/Volumeo2lssueo8-09

\begin{tabular}{|c|c|c|c|c|c|}
\hline 4 & 268 & 9,3 & 243 & 6,5 & 227 \\
\hline 5 & 292 & 7,9 & 269 & 5,6 & 254 \\
\hline 6 & 280 & 8,2 & 257 & 6,0 & 242 \\
\hline 7 & 305 & 7,5 & 282 & 5,2 & 267 \\
\hline 8 & 296 & 7,4 & 274 & 5,8 & 258 \\
\hline 9 & 268 & 8,2 & 246 & 6,2 & 231 \\
\hline 10 & 261 & 10,0 & 235 & 6,6 & 219 \\
\hline 11 & 290 & 7,9 & 267 & 5,6 & 252 \\
\hline 12 & 276 & 8,3 & 253 & 5,1 & 240 \\
\hline 13 & 309 & 6,8 & 288 & 4,8 & 274 \\
\hline 14 & 297 & 6,7 & 277 & 4,5 & 265 \\
\hline 15 & 318 & 6,3 & 298 & 4,1 & \\
\hline 16 & 312 & 6,1 & 293 & & \\
\hline
\end{tabular}

The above rules are reflected in the second irrigation regime, when the pre-irrigation soil moisture is $70-80-70 \%$ relative to the LFMC, in addition to the norms of mineral fertilizers N200P140K100kg / ha, 1.5-3.0-4.5 t per hectare. In the variants using bentonite mud, the actual seedling thickness was 252274-286 m2 / piece, the number of dead seedlings was 5.6-4.8-4.1\%, and the seedling thickness was 21-43-55 m2 / piece higher than the control. seedlings were found to be 0.6-1.4-2.1 percent lower. In addition to the norms of mineral fertilizers $\mathrm{N} 150 \mathrm{P} 105 \mathrm{~K} 75 \mathrm{~kg} / \mathrm{ha}, 1.5-3.0-4.5 \mathrm{t}$ per hectare. In the variants with bentonite mud, the actual seedling thickness was 240-265-280 m2 / grain, the number of dead seedlings was 5.1-4.5-4.4\%, and the seedling thickness was 21-46-61 m2 / grain higher than the control. , the number of dead seedlings decreased by $1.5-2.1-2.2 \%$. 
The data obtained show that in addition to the mineral fertilizer standards, in the variants where bentonite mud was used, the effect on seedling germination and actual seedling thickness was found to be significant.

Studies conducted in 2008-2009 and 2010-2011 also obtained data in accordance with the abovementioned legislation, in addition to mineral fertilizers, 1.5-3.0-4.5 t/ ha. It was observed that when bentonite mud was applied, the germination rate of seedlings increased and the mortality of seedlings decreased.

Accumulation of winter wheat is one of the main indicators. Some of the resulting stalks do not form spikes or grains in the spikes, while others form spikes. The total number of stems in a plant is called the total stem. Stems that form spikes and receive full grain are called productive stems or productive accumulations.

The results of the experiment show that along with the growth and development of winter wheat, the effect of irrigation regimens, mineral fertilizers and bentonite sludge on the total and number of productive stems was significant.

In particular, according to experiments conducted in 2010, pre-irrigation soil moisture was irrigated at $60-70-60 \%$ relative to the LFMC, and in addition to the norms of mineral fertilizers N200P140K100kg / ha, 1.5-3.0-4.5 t per hectare. In the variants with bentonite mud in the amount of 5.9-6.9-9.7 cm, the total number of stems is 49.0-96.6-104.7 m2 / piece and the number of productive stems is 47.4-97. , 7-102.2 $\mathrm{m} 2$ / piece, in addition to the norms of mineral fertilizers $\mathrm{N} 150 \mathrm{P} 105 \mathrm{~K} 75 \mathrm{~kg} / \mathrm{ha}, 1.5-3.0-4.5 \mathrm{t}$ per hectare. In the variants with the use of bentonite mud in the amount of 2.9-4.3-11.1 cm, the total number of stems is 81.6-99.4-108.3 m2 / piece, the number of productive stems is 76.1-100.3-107, More than $6 \mathrm{~m} 2 /$ piece.

In the second irrigation regime, the above laws were observed, pre-irrigation soil moisture was irrigated at $70-80-70 \%$ relative to the LFMC, and in addition to the norms of mineral fertilizers N200P140K100 kg / ha, 1.5-3.0-4.5 t per hectare. In 11-13-15 variants, where bentonite mud was applied in the amount of $91.1-93.5-95.7 \mathrm{~cm}$ by the end of the validity period. The total number of stems is $445.1-456.7-487.4 \mathrm{mz}$ / grain, the number of productive stems is 404.0-416.7-446.5 $\mathrm{m} 2$ / grain, and the height of the plant compared to the control is $3.9-6.3 .-8.5 \mathrm{~cm}$. In addition to the norms of mineral fertilizers $\mathrm{N} 150 \mathrm{P} 105 \mathrm{~K} 75 \mathrm{~kg} / \mathrm{ha}$, if the total number of stems is higher than $44.2-$ 55.8-86.5 m2 / piece, the number of productive stems is higher than 47.5-60.2-90.0 m2 / piece. 1.53.0-4.5 $\mathrm{t}$ per hectare. By the end of the growing season, the plant height was $88.7-91.1-93.5 \mathrm{~cm}$, the total number of stems was 437.3-455.7-487.2 $\mathrm{m2} /$ piece, and the number of productive stems was 397.1. - 415.5-444.5 $\mathrm{m} 2$ / piece, compared to the control variant, the plant height is $5.8-8.2-10.6 \mathrm{~cm}$, the total number of stems is $42.4-60.8-92.3 \mathrm{mz} /$ piece. , the number of productive stems is higher than 61.2-79.6-108.6 $\mathrm{mz} /$ piece.

\section{Table 6}

Height of autumn wheat, total and number of productive stalks, 2010 
The American Journal of Agriculture And Boimedical Engineering (ISSN - 2689-1018)

Published: August 30, 2020 | Pages: 73-97

Doi: https://doi.org/10.37547/tajabe/Volume02Issue08-09

\begin{tabular}{|c|c|c|c|c|c|c|}
\hline \multirow{2}{*}{ № } & \multirow{2}{*}{ Variants } & \multicolumn{3}{|c|}{$\begin{array}{l}\text { Height of plants, } \\
\qquad \mathrm{cm}\end{array}$} & \multirow{2}{*}{$\begin{array}{c}\text { Total } \\
\text { number of } \\
\text { stems, } \\
\mathrm{m}^{2} / \text { piece }\end{array}$} & \multirow{2}{*}{$\begin{array}{l}\text { The number of } \\
\text { productive } \\
\text { stems, } \mathrm{m}^{2} / \text { piece }\end{array}$} \\
\hline & & 1.04 & 1.05 & 1.06 & & \\
\hline 1 & Without bentonite & 37,7 & 82,0 & 82,8 & 379,1 & 332,8 \\
\hline 2 & Without bentonite & 34,5 & 76,7 & 79,7 & 344,9 & 300,4 \\
\hline 3 & $\begin{array}{l}1500 \mathrm{~kg} / \mathrm{ha} \\
\text { bentonite }\end{array}$ & 38,5 & 85,6 & 88,7 & 428,1 & 380,2 \\
\hline 4 & $\begin{array}{l}1500 \mathrm{~kg} / \mathrm{ha} \\
\text { bentonite }\end{array}$ & 36,1 & 79,0 & 82,6 & 426,5 & 376,5 \\
\hline 5 & $\begin{array}{l}3000 \mathrm{~kg} / \mathrm{ha} \\
\text { bentonite }\end{array}$ & 38,7 & 86,8 & 89,7 & 475,7 & 430,5 \\
\hline 6 & $\begin{array}{l}3000 \mathrm{~kg} / \mathrm{ha} \\
\text { bentonite }\end{array}$ & 35,7 & 82,3 & 84,0 & 444,3 & 400,7 \\
\hline 7 & $\begin{array}{l}4500 \mathrm{~kg} / \mathrm{ha} \\
\text { bentonite }\end{array}$ & 39,0 & 91,5 & 92,5 & 483,8 & 435,0 \\
\hline 8 & $\begin{array}{l}4500 \mathrm{~kg} / \mathrm{ha} \\
\text { bentonite }\end{array}$ & 36,2 & 87,9 & 90,8 & 453,2 & 408,0 \\
\hline 9 & Without bentonite & 39,4 & 87,1 & 87,2 & 400,9 & 356,5 \\
\hline 10 & Without bentonite & 36,8 & 81,9 & 82,9 & 394,9 & 335,9 \\
\hline
\end{tabular}




\begin{tabular}{|c|c|c|c|c|c|c|}
\hline 11 & $\begin{array}{c}1500 \mathrm{~kg} / \mathrm{ha} \\
\text { bentonite }\end{array}$ & 39,9 & 88,3 & 91,1 & 445,1 & 404,0 \\
\hline 12 & $\begin{array}{c}1500 \mathrm{~kg} / \mathrm{ha} \\
\text { bentonite }\end{array}$ & 37,0 & 85,9 & 88,7 & 437,3 & 397,1 \\
\hline 13 & $\begin{array}{c}3000 \mathrm{~kg} / \mathrm{ha} \\
\text { bentonite }\end{array}$ & 40,0 & 90,1 & 93,5 & 456,7 & 416,7 \\
\hline 14 & $\begin{array}{c}3000 \mathrm{~kg} / \mathrm{ha} \\
\text { bentonite }\end{array}$ & 37,5 & 88,2 & 91,1 & 455,7 & 415,5 \\
\hline 15 & $\begin{array}{c}4500 \mathrm{~kg} / \mathrm{ha} \\
\text { bentonite }\end{array}$ & 40,5 & 94,8 & 95,7 & 487,4 & 446,5 \\
\hline 16 & $\begin{array}{c}4500 \mathrm{~kg} / \mathrm{ha} \\
\text { bentonite }\end{array}$ & 38,1 & 92,2 & 93,5 & 487,2 & 444,5 \\
\hline
\end{tabular}

In our 2009 and 2011 studies, the same patterns were observed, with significant effects of bentonite sludge, mineral fertilizer rates, and irrigation regimens on the height of winter wheat and the number of total and productive stalks.

The spike length of the autumn wheat crop, the number of grains in the spike, the weight of the grain in one spike, and the grain weight of 1000 grains are important indicators of wheat yield.

In our experiment from 2008 to 2011, it was observed that the effect of bentonite mud and mineral fertilizers norms and irrigation regimes on the yield elements of winter wheat was specific.

In particular, based on the results of experiments in 2010, pre-irrigation soil moisture was irrigated at $60-70-60 \%$ relative to LFMC, mineral fertilizers were applied at the rate of $\mathrm{N} 200 \mathrm{P} 140 \mathrm{~K} 100 \mathrm{~kg} / \mathrm{ha}$, in option 1 (control) the average spike length was $8.6 \mathrm{~cm}$, the number of grains per grain is 38.1 grains, the weight of grain per grain is $1.43 \mathrm{~g}$ and the weight of 1000 grains is $37.6 \mathrm{~g} \cdot 1.5-3.0-4.5 \mathrm{t}$ per hectare in addition to the norms of mineral fertilizers. In the 3-5-7 variants, where bentonite mud was used in the amount of $8-7-8.9-8.9 \mathrm{~cm}$, the average spike length, respectively. The number of grains per grain is 
38.2-38.3-39.1 grains, the weight of grain per grain is $1.48-1.48-1.53 \mathrm{~g}$. and the weight of 1000 grains is $38.6-38.7-39.1 \mathrm{~g}$. showed that.

In the control of variant 2, which was irrigated in this irrigation regime and applied norms of mineral fertilizers $\mathrm{N} 150 \mathrm{P} 105 \mathrm{~K} 75 \mathrm{~kg} / \mathrm{ha}$, the average grain length was $8.3 \mathrm{~cm}$, the number of grains per grain was 38.0, and the weight of grain per grain was $1.39 \mathrm{~g}$. and 1000 grains weighing 36.5 g. 1.5-3,0-4,5 t per hectare in addition to the norms of these mineral fertilizers. In the case of bentonite mud (4-68 variants), the length of the spike is 8.5-8.7$8.8 \mathrm{~cm}$, respectively. The number of grains per grain is 38.1-38.2-38.8 grains, the average grain weight is $1.43-1.45-1.48 \mathrm{~g}$. and the weight of 1000 grains is $37.6-37.9-38.2 \mathrm{~g}$. It was noted that

Table 7

Effect of bentonite sludge on biometric indicators of autumn wheat, 2010

\begin{tabular}{|c|c|c|c|c|c|}
\hline № & Variants & $\begin{array}{l}\text { The } \\
\text { length of } \\
\text { spite, cm }\end{array}$ & $\begin{array}{l}\text { The number } \\
\text { of crops on } \\
\text { one spite, } \\
\text { piece }\end{array}$ & $\begin{array}{c}\text { The weight of } \\
\text { crops on one } \\
\text { spite, gr }\end{array}$ & $\begin{array}{l}\text { The weight } \\
\text { of } 1000 \\
\text { pieces of } \\
\text { crops, gr }\end{array}$ \\
\hline 1 & Without bentonite & 8,6 & 38,1 & 1,43 & 37,6 \\
\hline 2 & Without bentonite & 8,3 & 38,0 & 1,39 & 36,5 \\
\hline 3 & $\begin{array}{l}1500 \mathrm{~kg} / \mathrm{ha} \\
\text { bentonite }\end{array}$ & 8,7 & 38,2 & 1,48 & 38,6 \\
\hline 4 & $\begin{array}{l}1500 \mathrm{~kg} / \mathrm{ha} \\
\text { bentonite }\end{array}$ & 8,5 & 38,1 & 1,43 & 37,6 \\
\hline 5 & $\begin{array}{l}3000 \mathrm{~kg} / \mathrm{ha} \\
\text { bentonite }\end{array}$ & 8,9 & 38,3 & 1,48 & 38,7 \\
\hline
\end{tabular}


The American Journal of Agriculture And Boimedical Engineering (ISSN - 2689-1018)

Published: August 30, 2020 | Pages: 73-97

Doi: https://doi.org/10.37547/tajabe/Volumeo2Issueo8-09

\begin{tabular}{|c|c|c|c|c|c|}
\hline 6 & $\begin{array}{l}3000 \mathrm{~kg} / \mathrm{ha} \\
\text { bentonite }\end{array}$ & 8,7 & 38,2 & 1,45 & 37,9 \\
\hline 7 & $\begin{array}{l}4500 \mathrm{~kg} / \mathrm{ha} \\
\text { bentonite }\end{array}$ & 8,9 & 39,1 & 1,53 & 39,1 \\
\hline 8 & $\begin{array}{l}4500 \mathrm{~kg} / \mathrm{ha} \\
\text { bentonite }\end{array}$ & 8,8 & 38,8 & 1,48 & 38,2 \\
\hline 9 & Without bentonite & 8,8 & 38,5 & 1,49 & 38,7 \\
\hline 10 & Without bentonite & 8,5 & 38,1 & 1,41 & 37,0 \\
\hline 11 & $\begin{array}{l}1500 \mathrm{~kg} / \mathrm{ha} \\
\text { bentonite }\end{array}$ & 9,0 & 38,7 & 1,50 & 38,9 \\
\hline 12 & $\begin{array}{l}1500 \mathrm{~kg} / \mathrm{ha} \\
\text { bentonite }\end{array}$ & 8,9 & 38,5 & 1,47 & 38,1 \\
\hline 13 & $\begin{array}{l}3000 \mathrm{~kg} / \mathrm{ha} \\
\text { bentonite }\end{array}$ & 9,3 & 38,7 & 1,52 & 39,2 \\
\hline 14 & $\begin{array}{l}3000 \mathrm{~kg} / \mathrm{ha} \\
\text { bentonite }\end{array}$ & 9,2 & 38,5 & 1,50 & 39,0 \\
\hline 15 & $\begin{array}{l}4500 \mathrm{~kg} / \mathrm{ha} \\
\text { bentonite }\end{array}$ & 9,5 & 39,5 & 1,57 & 39,6 \\
\hline 16 & $\begin{array}{l}4500 \mathrm{~kg} / \mathrm{ha} \\
\text { bentonite }\end{array}$ & 9,2 & 39,3 & 1,54 & 39,2 \\
\hline
\end{tabular}


In the second irrigation regime (70-80-70\% of the LFMC), the same pattern was observed. , a spike weighing $1.49 \mathrm{~g}$. and $38.7 \mathrm{~g}$ per 1,000 grains. 1.5-3.0-4.5 t per hectare in addition to the norm of these mineral fertilizers. In variants 11-13-15, where the amount of bentonite mud was used in the amount of 9.0-9.3-9.5 cm. The number of grains in one grain is 38.7-38.7-39.5 grains, the weight of one grain is $1.5-1.52-1.57 \mathrm{~g}$. and 1000 grains weighing 38.9-39.2-39.6 g. These indicators are based on the fact that mineral fertilizers $\mathrm{N} 150 \mathrm{P} 105 \mathrm{~K} 75 \mathrm{~kg} /$ ha used in the norm of control 10 - variant, the average length of a spike is $8.5 \mathrm{~cm}$. The number of grains in a grain is 38.1 grains, the weight of a grain is $1.41 \mathrm{~g}$. ni, 1000 pieces of grain weight $37.0 \mathrm{~g}$. 1.5-3.0-4.5 $t$ per hectare in addition to the norm of these mineral fertilizers. In 12-14-16 variants, the length of one spike is 8.9-9.2-9.2 cm, the number of grains per spike is 38.5-38.5-39.3, the weight of one spike is 1.47- 1.50-1.54 g. and the weight of 1000 grains was 38.1-39.0$39.2 \mathrm{~g}$. It was noted that

According to the data obtained, in addition to the norms of mineral fertilizers N200P140K100and N150P105K75 kg / ha, 3.0$4.5 \mathrm{t}$ per hectare. It was observed that the application of bentonite mud, the length of the grain, the number of grains per grain, the weight of the grain per grain and the weight of 1000 grains were significantly affected.

In the conditions of typical gray soils of Tashkent region, the requirements of winter wheat variety "Moskvich" for bentonite sludge, norms of mineral fertilizers and irrigation procedures were studied.

Accordingly, the pre-irrigation soil moisture was irrigated at $60-70-60 \%$ relative to the LFMC, and in the control variant of mineral fertilizers N200P140K100 kg / ha, the average grain yield was 46.4 ts / ha in three years, in addition to the norm of mineral fertilizers. 1.53.0-4.5 $t$ per hectare. The average yield of $53.3-55.2-56.5$ ts / ha was obtained in three years, respectively, with the use of bentonite mud (3-5-7 variants), with an additional 6.98.8-10.1 ts / ha grain yield was obtained. Irrigated in this irrigation regime, it was observed that the control of mineral fertilizers $\mathrm{N} 150 \mathrm{P} 105 \mathrm{~K} 75 \mathrm{~kg} / \mathrm{ha}$ yielded an average grain yield of 41.5 ts / ha in three years (43.7-40.240.5) from option 2, which is in line with the standards of these mineral fertilizers. in addition, 1.5-3.0-4.5 $\mathrm{t}$ per hectare. In the variants with the use of bentonite mud (4-68), the grain yield was 52.8-54.9-56.2 $\mathrm{t} / \mathrm{ha}$, espectively, and 11.3-13.4-14.7 $\mathrm{t} / \mathrm{h}$ ho more than the control. was found to be a grain crop.

\section{Table 8}

Irrigation regime, norm of mineral fertilizers and autumn wheat grain and straw of bentonite mud

effect on productivity

\begin{tabular}{|l|l|l|l|l|}
\hline № & Variants & Pre-irrigation & Mineral & Grain yield, ts / ha \\
\hline
\end{tabular}


The American Journal of Agriculture And Boimedical Engineering (ISSN - 2689-1018)

Published: August 30, 2020 | Pages: 73-97

Doi: https://doi.org/10.37547/tajabe/Volumeo2Issueo8-09

\begin{tabular}{|c|c|c|c|c|c|c|c|}
\hline & & $\begin{array}{c}\text { soil moisture } \\
\text { relative to } \\
\text { LFMC }\end{array}$ & $\begin{array}{c}\text { Fertilizer } \\
\text { Norm, NPK }\end{array}$ & 2009 & 2010 & 2011 & Total \\
\hline 1 & $\begin{array}{l}\text { Without } \\
\text { bentonite }\end{array}$ & & 200-140-100 & 48,8 & 44,6 & 45,8 & 46,4 \\
\hline 2 & $\begin{array}{l}\text { Without } \\
\text { bentonite }\end{array}$ & & $150-105-75$ & 43,7 & 40,2 & 40,5 & 41,5 \\
\hline 3 & $\begin{array}{c}1500 \\
\mathrm{kgg} / \mathrm{ha} \\
\text { bentonite }\end{array}$ & & 200-140-100 & 58,3 & 53,3 & 48,2 & 53,3 \\
\hline 4 & $\begin{array}{c}1500 \\
\mathrm{kgg} / \mathrm{ha} \\
\text { bentonite }\end{array}$ & & $150-105-75$ & 57,9 & 52,9 & 47,5 & 52,8 \\
\hline 5 & $\begin{array}{c}3000 \\
\mathrm{kgg} / \mathrm{ha} \\
\text { bentonite }\end{array}$ & $\begin{array}{l}0 \\
0 \\
0 \\
1 \\
0 \\
1 \\
0\end{array}$ & 200-140-100 & 59,0 & 55,7 & 50,8 & 55,2 \\
\hline 6 & $\begin{array}{c}3000 \\
\mathrm{kgg} / \mathrm{ha} \\
\text { bentonite }\end{array}$ & & 150-105-75 & 58,7 & 55,4 & 50,6 & 54,9 \\
\hline 7 & $\begin{array}{c}4500 \\
\mathrm{kgg} / \mathrm{ha} \\
\text { bentonite }\end{array}$ & & 200-140-100 & 60,2 & 56,9 & 52,5 & 56,5 \\
\hline 8 & $\begin{array}{c}4500 \\
\mathrm{kgg} / \mathrm{ha} \\
\text { bentonite }\end{array}$ & & $150-105-75$ & 60,1 & 56,6 & 51,9 & 56,2 \\
\hline 9 & $\begin{array}{l}\text { Without } \\
\text { bentonite }\end{array}$ & $\begin{array}{ll}1 & \\
0 & 8 \\
1 & 0 \\
0 & 1\end{array}$ & 200-140-100 & 52,2 & 48,4 & 46,1 & 48,9 \\
\hline
\end{tabular}


The American Journal of Agriculture And Boimedical Engineering (ISSN - 2689-1018)

Published: August 30, 2020 | Pages: 73-97

Doi: https://doi.org/10.37547/tajabe/Volumeo2Issueo8-09

\begin{tabular}{|c|c|c|c|c|c|c|}
\hline 10 & $\begin{array}{l}\text { Without } \\
\text { bentonite }\end{array}$ & $150-105-75$ & 48,9 & 43,6 & 42,3 & 44,9 \\
\hline 11 & $\begin{array}{c}1500 \\
\text { kgg/ha } \\
\text { bentonite }\end{array}$ & 200-140-100 & 58,6 & 55,5 & 49,3 & 54,5 \\
\hline 12 & $\begin{array}{c}1500 \\
\text { kgg/ha } \\
\text { bentonite }\end{array}$ & 150-105-75 & 58,0 & 55,3 & 49,7 & 54,3 \\
\hline 13 & $\begin{array}{c}3000 \\
\mathrm{kgg} / \mathrm{ha} \\
\text { bentonite }\end{array}$ & 200-140-100 & 60,4 & 59,0 & 52,0 & 57,1 \\
\hline 14 & $\begin{array}{c}3000 \\
\mathrm{kgg} / \mathrm{ha} \\
\text { bentonite }\end{array}$ & $150-105-75$ & 59,8 & 58,8 & 51,8 & 56,8 \\
\hline 15 & $\begin{array}{c}4500 \\
\mathrm{kgg} / \mathrm{ha} \\
\text { bentonite }\end{array}$ & 200-140-100 & 62,9 & 60,8 & 52,9 & 58,9 \\
\hline 16 & $\begin{array}{c}4500 \\
\mathrm{kgg} / \mathrm{ha} \\
\text { bentonite }\end{array}$ & 150-105-75 & 62,6 & 60,5 & 52,5 & 58,5 \\
\hline
\end{tabular}

\begin{tabular}{|c|c|c|c|}
\hline \multicolumn{4}{|c|}{ Straw yield, ts / ha } \\
\hline 2009 & 2010 & 2011 & Total \\
\hline 57,6 & 53,0 & 53,7 & 54,8 \\
\hline 51,1 & 47,3 & 47,3 & 48,6 \\
\hline
\end{tabular}


The American Journal of Agriculture And Boimedical Engineering (ISSN - 2689-1018)

Published: August 30, 2020 | Pages: 73-97

Doi: https://doi.org/10.37547/tajabe/Volumeo2Issueo8-09

\begin{tabular}{|c|c|c|c|}
\hline 78,9 & 71,4 & 65,2 & 71,8 \\
\hline 71,6 & 65,1 & 58,7 & 65,1 \\
\hline 80,0 & 75,3 & 68,8 & 74,7 \\
\hline 71,8 & 68,6 & 62,1 & 67,5 \\
\hline 82,9 & 76,9 & 70,8 & 76,9 \\
\hline 74,5 & 69,1 & 62,8 & 68,8 \\
\hline 62,0 & 56,4 & 56,7 & 58,4 \\
\hline 57,1 & 51,8 & 51,5 & 53,5 \\
\hline 79,5 & 74,9 & 67,9 & 74,1 \\
\hline 71,8 & 67,9 & 60,7 & 66,8 \\
\hline 82,3 & 79,2 & 70,9 & 77,5 \\
\hline 73,6 & 72,1 & 63,1 & 69,6 \\
\hline 84,6 & 81,6 & 72,1 & 79,4 \\
\hline 77,0 & 74,8 & 64,2 & 72,0 \\
\hline
\end{tabular}

The second irrigation regime was carried out when the pre-irrigation soil moisture was 70$80-70 \%$ relative to the $\mathrm{LFMC}$, and mineral fertilizers were applied at the rate of N200P140K10okg / ha. Control variant 9 yielded an average grain yield of 48.9 ts / ha in three years. in addition, 1.5-3.0-4.5 t per hectare. When using bentonite mud, the grain yield was 54.5-57.1-58.9 ts / ha, respectively, and 5.6-8.2-10.0 ts / ha more than the control variant. In this irrigation procedure, the standard yield of mineral fertilizers N150P105K75kg / ha was obtained from the control variant 10 with an average grain yield of $44.9 \mathrm{t} / \mathrm{ha}$ in three years, in addition to the norms of these mineral fertilizers 1.5-3.0-4.5 $\mathrm{t} /$ ha. 54.3-56.8-58.5 ts / ha of grain were harvested in three years from the 12-14-16 variants using bentonite mud in the amount of 9.4-11.9-13.6 ts / ha in addition to the control. yield was obtained.

The data show that the effect of bentonite mud, mineral fertilizer standards and irrigation regimes on the grain yield of winter wheat was significant.

Grain quality indicators vary depending on soil climatic conditions, agro-technical measures 
taken and the factors used. Accordingly, the quality indicators were determined in the section of options depending on the factors used in the experimentally grown grain yield.

The obtained data show that the pre-irrigation soil moisture is irrigated in the order of 60$70-60 \%$ relative to the LFMC, mineral

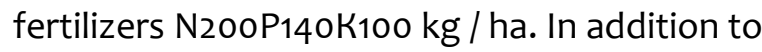
the norms of these mineral fertilizers, 1.5-3.0$4.5 \mathrm{t}$ per hectare. When determining the quality of grain obtained from 3-5-7 variants using bentonite mud in the amount of 14.6$14.9-15.0 \%$, the amount of gluten was $27.9-$ $28.7-29.0 \%$, compared to the control variant. protein content was found to be $0.4-0.7-0.8 \%$, and gluten content was found to be 0.4-1.2$1.5 \%$ higher.

When analyzing the grain content of the control variant, which was irrigated in this irrigation regime and applied mineral fertilizers $\mathrm{N} 150 \mathrm{P} 105 \mathrm{~K} 75 \mathrm{~kg} / \mathrm{ha}$, the protein content was $14.0 \%$, gluten content was $26.9 \%$. 3.0-4.5 t. In 4-6-8 variants with bentonite turbidity, the protein content was 14.3-14.5$14.7 \%$, the gluten content was $27.2-27.9-28.3 \%$, and the protein content was 0.3 compared to the control variant. $-0.5-0.7 \%$, gluten content was observed to be $0.3-1.0-1.4 \%$ higher.

\section{Table 9}

Irrigation regime, mineral fertilizer rates and the effect of bentonite turbidity on grain quality indicators

\begin{tabular}{|c|c|c|c|c|c|}
\hline \multirow{2}{*}{ № } & \multirow{2}{*}{ Variants } & \multirow{2}{*}{$\begin{array}{c}\text { According } \\
\text { to LFMC, } \\
\%\end{array}$} & \multirow{2}{*}{$\begin{array}{c}\text { Norm of } \\
\text { mineral } \\
\text { fertilizers, } \\
\text { NPK (кг/га) }\end{array}$} & \multicolumn{2}{|c|}{$\begin{array}{c}\text { Structural properties, } \\
\%\end{array}$} \\
\hline & & & & Protein & Gluten \\
\hline 1 & Without bentonite & \multirow{3}{*}{$60-70-60$} & $\begin{array}{c}200-140- \\
100\end{array}$ & 14,2 & 27,5 \\
\hline 2 & Without bentonite & & $150-105-75$ & 14,0 & 26,9 \\
\hline 3 & $\begin{array}{l}1500 \mathrm{~kg} / \mathrm{ha} \\
\text { bentonite }\end{array}$ & & $\begin{array}{c}200-140- \\
100\end{array}$ & 14,6 & 27,9 \\
\hline
\end{tabular}


The American Journal of Agriculture And Boimedical Engineering (ISSN - 2689-1018)

Published: August 30, 2020 | Pages: 73-97

Doi: https://doi.org/10.37547/tajabe/Volumeo2Issueo8-09

\begin{tabular}{|c|c|c|c|c|c|}
\hline 4 & $\begin{array}{l}1500 \text { kg/ha } \\
\text { bentonite }\end{array}$ & & 150-105-75 & 14,3 & 27,2 \\
\hline 5 & $\begin{array}{l}3000 \mathrm{~kg} / \mathrm{ha} \\
\text { bentonite }\end{array}$ & & $\begin{array}{c}200-140- \\
100\end{array}$ & 14,9 & 28,7 \\
\hline 6 & $\begin{array}{l}3000 \mathrm{~kg} / \mathrm{ha} \\
\text { bentonite }\end{array}$ & & 150-105-75 & 14,5 & 27,9 \\
\hline 7 & $\begin{array}{l}4500 \mathrm{~kg} / \mathrm{ha} \\
\text { bentonite }\end{array}$ & & $\begin{array}{c}200-140- \\
100\end{array}$ & 15,0 & 29,0 \\
\hline 8 & $\begin{array}{l}4500 \mathrm{~kg} / \mathrm{ha} \\
\text { bentonite }\end{array}$ & & 150-105-75 & 14,7 & 28,3 \\
\hline 9 & Without bentonite & \multirow{6}{*}{$70-80-70$} & $\begin{array}{c}200-140- \\
100\end{array}$ & 13,3 & 26,2 \\
\hline 10 & Without bentonite & & $150-105-75$ & 13,0 & 25,5 \\
\hline 11 & $\begin{array}{l}1500 \mathrm{~kg} / \mathrm{ha} \\
\text { bentonite }\end{array}$ & & $\begin{array}{c}200-140- \\
100\end{array}$ & 13,9 & 26,6 \\
\hline 12 & $\begin{array}{l}1500 \mathrm{~kg} / \mathrm{ha} \\
\text { bentonite }\end{array}$ & & 150-105-75 & 13,5 & 26,0 \\
\hline 13 & $\begin{array}{l}3000 \mathrm{~kg} / \mathrm{ha} \\
\text { bentonite }\end{array}$ & & $\begin{array}{c}200-140- \\
100\end{array}$ & 14,1 & 27,5 \\
\hline 14 & $3000 \mathrm{~kg} / \mathrm{ha}$ & & $150-105-75$ & 13,9 & 26,7 \\
\hline
\end{tabular}




\begin{tabular}{|c|c|c|c|c|c|}
\hline & bentonite & \multirow{2}{*}{1} & & \\
\cline { 5 - 5 } 15 & $\begin{array}{c}4500 \mathrm{~kg} / \mathrm{ha} \\
\text { bentonite }\end{array}$ & & $\begin{array}{c}200-140- \\
100\end{array}$ & 14,2 & 27,8 \\
\cline { 4 - 5 } 16 & $\begin{array}{c}4500 \mathrm{~kg} / \mathrm{ha} \\
\text { bentonite }\end{array}$ & & $150-105-75$ & 14,1 & 27,1 \\
\cline { 5 - 6 } & & & & \\
\hline
\end{tabular}

In the second irrigation regime, when the preirrigation soil moisture is $70-80-70 \%$ relative to the LFMC, we can see that the above patterns are repeated in the data obtained from the irrigated options, the protein content of grain obtained from the control variant 9 of mineral fertilizers N200P140K100kg / ha 13.3 percent, gluten content was 26.2 percent, in addition to the norms of these mineral fertilizers 1.5-3.0-4.5 $t$ per hectare. Analysis of grain quality from 1113-15 variants using bentonite mud in the amount of $13.9-14.1-14.2 \%$ of protein and $26.6-$ $27.5-27.8 \%$ of gluten It was observed that the protein content was $0.6-0.8-0.9 \%$ higher and the gluten content was $0.4-1.3-1.6 \%$ higher.

Irrigated in this irrigation mode, when the quality of grain obtained from the control variant 10 using the norms of mineral fertilizers $\mathrm{N} 150 \mathrm{P} 105 \mathrm{~K} 75 \mathrm{~kg} \mathrm{/} \mathrm{ha} \mathrm{showed} \mathrm{a}$ reasonable content of $13.0 \%$, gluten content of $25.5 \%$, in addition to the norms of these mineral fertilizers 1.5-3 per hectare. , 0-4.5 t. In the analysis of grain quality from 12-14-16 variants using bentonite turbidity, the protein content was $13.5-13.9-14.1 \%$, and the gluten content was $26.0-26.7-27.1 \%$. It was noted that the protein content is $0.5-0.9-1.1 \%$ higher and the gluten content is $0.5-1.2-1.6 \%$ higher.
The data show that the application of bentonite mud in the amount of 3.0-4.5 $\mathrm{t} / \mathrm{ha}$ under the drive in addition to mineral fertilizers has a positive effect on grain quality, the amount of protein when irrigated in the pre-irrigation soil moisture $60-70-60 \%$ relative to the LFMC 0.7-0.8\%, gluten content $1.4-1.5 \%$, pre-irrigation soil moisture $70-80-70 \%$ relative to LFMC when irrigated in the order of irrigation, protein content $0.9-0.1 .1 \%$, gluten content Which was 1.6 percent higher.

\section{CONCLUSIONS}

1. In the typical gray soils of Tashkent region, bentonite mud in the amount of $3.0 \mathrm{t} / \mathrm{ha}$ is applied to the plow once every three years. When irrigated, the weight of the soil volume ranges from $0.03-0.05 \mathrm{~g} / \mathrm{cm} 3$ in the $0-30 \mathrm{~cm}$ layer to $0.07-0.08 \mathrm{~g} / \mathrm{cm} 3$ in the $0-30 \mathrm{~cm}$ layer, and on average $0.07 \mathrm{~g} / \mathrm{cm} 3$ in the 30-50 layer. Decreased to $11 \mathrm{~g} / \mathrm{cm} 3$, and soil water permeability was found to increase from $30 \mathrm{~m} 3$ / ha to $100 \mathrm{~m} 3$ / ha.

2. In addition to the norms of mineral fertilizers, $3.0 \mathrm{t} /$ ha of bentonite mud was applied under the plow. When irrigated in the order of $80-70 \%$, it is possible to save $790 \mathrm{~m} 3$ / ha of water.

3. When pre-irrigation soil moisture is irrigated in the order of $60-70-60$ and 
$70-80-70 \%$ relative to the LFMC, in addition to the norms of mineral fertilizers $\mathrm{N} 150 \mathrm{P} 105 \mathrm{~K} 75 \mathrm{~kg} / \mathrm{ha}, 3.0 \mathrm{t} / \mathrm{ha}$ of bentonite sludge is applied under the drive. actual seedling thickness up to 33$46 \mathrm{~m} 2$ / piece, height up to $4.3-8.2 \mathrm{~cm}$, total number of stems up to 608.0-994.0 thousand / ha, and the number of productive stems up to $0.796-1.003$ million / ha observed.

4. When pre-irrigated soil moisture is 60$70-60$ and $70-80-70 \%$ relative to the LFMC, in addition to the norms of mineral fertilizers $\mathrm{N} 150 \mathrm{P} 105 \mathrm{~K} 75 \mathrm{~kg} /$ ha when applying bentonite mud in the amount of $3.0 \mathrm{t} / \mathrm{ha}$ under the drive, an additional 11, Grain yield was 9-13.4 ts / ha, and the yield was high, ranging from $21.1-18.9 \%$.

\section{REFERENCES}

1. M. El - Nennah and A.Abdel Latif, Soils Dept., Ain Shams University and Soil \& Water Research Institute, Cairo / Egypt "Soils in Mediterranean Type Climates and their Yield Potential" // Proceedings of the 14th Colloquium of the International Potash Institute held in Sevilla / Spain 1979. R. 213-215.

2. Sokolov A.S. Informatsionnye materialy VNTsI sistemnyx issledovaniy AN SSSR. Vyp. 3, 1982. p. 28-29.

3. Distanov U.G. Netraditsionnye vidy mineralnogo syrya dlya selskogo xozyaystva. V kn .: Geologist. Methods of searching and exploration of non-ferrous metals, M. VNIEMSI, 1985. p. 85-105.

4. Tsygankov A.V. "Application of bentonite and mineral fertilizers under winter wheat in dark-chestnut soil" "Abstract of the candidate of agricultural sciences" Persianovskiy - 2011. S. 9-16.

5. Agafonov E.V.,. Tsygankov A.V., Turchin V.V., Gromakov A.A. "Application of bentonite clay under ozimuyu pshenitsu in dark - chestnut soil" // J. "Agrochemical Herald" 2013 №3. S. 22-24.

6. Tungushova DA, Abdurahmanov SO, Belousov EM, Boltaev SM "The effect of bentonite mud on the growth, development and yield of cotton" // Uzbek Cotton Research Institute. Collection of articles on the basis of reports of the international scientificpractical conference "Scientific and practical bases of increasing soil fertility" (Part I). Tashkent - 2007. B. 291-292.

7. Abduraxmonov C. "Optimization of water-nutrient regimes of cotton using bentonite sludge in combination with mineral fertilizers" // Collection of scientific articles of the scientific-practical conference "Young scientists - a leading force in improving the science and practice of agriculture." Tashkent - 2008. B. 23-27.

8. Abdullaev I.I., Abduraxmonov S.O. "Bentonite glina and urojay zerna" // "Actual problems of modern science" .Russia - № 2 (99) 2018. - C. 52-56. 